\title{
Academic English and elite masculinities
}

Roslyn Appleby

Roslyn.Appleby@uts.edu.au

\begin{abstract}
This paper addresses the ways in which the teaching of English for academic purposes by 'Western' teachers in Japanese higher education institutions is shaped by gender and sexuality. The paper draws on findings from a 5 year ethnographic study of white Western teachers of English in Japan. Drawing on interview data with 18 male participants, the paper points to the way elite status is attached to the teaching of English for academic purposes (TEAP) in contrast with teaching general English; the way TEAP is reproduced as a male-dominated activity among English-native-speaker teachers; and the way white Western men teaching in these contexts display an enhanced professional masculinity. Discourses articulated by the men also serve to position gendered Others as illegitimate or unworthy participants in TEAP. Although the men's accounts tend to frame TEAP as a rational, disembodied, asexual occupation, the paper argues that gender and sexuality are deployed as identity gatekeeping tools that serve to police the borders of academic English as an elite, male-dominated professional category. In closing, I make proposals for transformation of gendered hierarchies in this context, but these would require shifts in deep-seated cultural, institutional, and interpersonal gender ideologies.
\end{abstract}

\section{Keywords:}




\section{Introduction}

This paper considers the ways in which the teaching of English for Academic Purposes (TEAP) may be shaped by discourses of gender and sexuality. It draws on data generated in a 5 year ethnographic research project that sought to investigate the effects of gender and sexuality in the professional and personal experiences of white 'Western' ${ }^{1}$ men and women who taught English to adults in Japanese postcompulsory education contexts. My focus in this paper is on a specific part of the study, interview data with 18 Western men in regard to teaching academic English in Japanese universities. My analysis of this data addresses the following research questions:

- How do Western male educators construct TEAP as a professional activity?

- How do Western male educators construct TEAP as a gendered form of labour?

I begin with an overview of gender distribution among teachers of English in Japan, drawing on professional association membership data and Japanese international marriage statistics that provide a partial map indicating male dominance. I also

\footnotetext{
${ }^{1}$ I recognise that terms such as 'white' and 'Western' are contentious, and have been extensively problematized in critical whiteness and race studies. In line with contemporary scholarship, I see both 'whiteness' and 'Western' (and 'heterosexuality) as discursive constructions and ascribed identity markers that have significant material and structural consequences. Here, they are used to denote English language teachers who are so-called 'native speakers' of English from what is considered to be the Anglophone Centre, that is, the USA, UK, Canada, Australia or New Zealand, where English is regarded as the dominant first language. In the global English language teaching industry, white native speaker privilege has been widely documented but gendered hierarchies have received relatively limited attention.
} 
provide a working definition of TEAP in this context. I then describe the larger study on which this paper is based before introducing the specific dataset and analytical framework used in this paper. In discussing my analysis, I draw primarily on male participants' interview data to demonstrate how an elite status is attached to the teaching of male-dominated EAP and how the boundaries of TEAP are policed through discourses that serve to exclude a range of Others, in particular Western women.

\section{Gender distribution in the teaching English for Academic Purposes in Japan}

For many Western men (and women) who wish to work in Japan, English language teaching provides employment opportunities in a range of institutional contexts. In the adult educational sector jobs fall into two main categories: first, private conversation schools (eikaiwa gakkō) such as Berlitz, ECC, Gaba, and AEON, which provide tuition in general English and tailored courses for business English; and second, public and private higher education colleges and universities where language tuition includes EAP and discipline-focused ESP. The status of employment in the higher education sector is shaped, in part, by institutional and employment hierarchies. Higher education institutions range in status from small, private two-year liberal arts colleges at the lower end, up to prestigious national public universities. In terms of university employment status, this ranges in prestige from relatively low-level parttime positions, through fixed term contracts, to fully tenured positions (for more detail on university employment categories and institutional hierarchies, see Nagatomo 2012, 2016). A third, smaller category of employment is with private companies that supply instructors for in-house corporate language training. 
The context in which this study took place was in EAP at university level and I use 'TEAP' throughout this paper to capture three key notions. 1). As an empirical description of the context in which participants worked, that is as teachers of English in universities; 2) As indexing a particular subjectivity and positionality with regard to what constitutes EAP. The educators I interviewed positioned themselves as, inter alia, teachers of EAP, and this was a major part of the subjectivity that they projected when speaking of their university work which they described as encompassing, for example, inducting students into the genres, discourse features and academic skills characteristic of specific faculties or institutions where they were enrolled. Thus, in terms of subjectivity, a primary focus of the men's talk about their teaching work concerned their efforts to place themselves in opposition to the teaching of general English or casual conversation (commonly associated with conversation schools) and to place themselves in a higher-status category of employment that included the teaching of English for academic purposes. 3) As signaling a poststructuralist approach to accounts of identity as fluid, multiple, and highly contextualised, rather than tied to the teaching of clearly delineated content matter (for further detailed discussion of fluid and contingent professional identities and English language educators in Japanese universities see Fraser 2011).

The qualifications required of Westerners applying to teach English in conversation schools is often only that they are, or can pass as, 'native-speakers' of English, whereas employment in colleges and universities often requires a Masters degree, TESOL experience, and 'native-speaker' ability. Indeed, of the men at the centre of this study, most had eventually achieved doctoral qualifications in languagerelated fields. Perhaps even more importantly, securing work in university EAP in 
most cases depends on making personal connections, initially attaining casual university work through word-of-mouth, and then maintaining networks in which job information is shared, and thereby building a resume that is more attractive to potential employers (Appleby, 2014). This process serves to maintain existing gender structures in the workplace, as will be discussed in later sections.

In higher education institutions there are marked gendered patterns of employment among both Western and Japanese teachers. The exact gender breakdown of English language teachers in Japan is difficult to determine but some indications can be gleaned from higher education employment statistics published in Japan. In two-year colleges (awarding associate degrees and diplomas), the number of Japanese male and female staff members is roughly equal, but among foreign (nonJapanese) staff men outnumber women by approximately two to one (MEXT 2012). In Japanese universities, men occupy almost four out of every five academic positions and among non-Japanese staff, men outnumber women by three to one in full-time positions. It is only in less secure casual academic appointments that the proportion of women increases slightly, though they still comprise only one third of staff in this category (MEXT 2012).

Although no definitive data is collected or published in regard to the number of academic English language teachers in the Japanese university system, estimates suggest that the pattern of gender disparity is even more pronounced in this subdiscipline category. Hayes (2013), for example, extrapolates from several sources to estimate that male teachers comprise up to 90 percent of the 1600 foreign (nonJapanese) full-time (mostly limited term contracts and some tenured) lecturers 
employed in English language teaching or related fields in Japanese higher education institutions. A further source of evidence for the predominance of foreign men across Japan's English language teaching industry can be seen in the membership of the Japanese Association for Language Teaching (JALT). In 2014, the non-Japanese membership of JALT stood at 1,727, of which 73 percent, were male (B. Green, Membership Director, JALT, personal communication 28 April 2014).

This contrasts with the gender pattern among 934 Japanese members of JALT, where Japanese men comprise only 32 percent of total membership. Although JALT does not exclusively draw its members from higher education institutions, it seems reasonable to assume that those Western teachers of English who attain employment in a university may be more likely to join a professional association than those who teach general English for only a year or two at lower level conversation schools.

The predominance of men among Western teachers of English in Japan stands in marked contrast to the predominance of women in centre-circle countries, if membership of professional organisations is taken as a guide. Based in the USA, 76 percent of TESOL International membership is female (R. Aronson, pers. comm. 23 July 2012) and the greatest proportion of members are employed in postsecondary education (TESOL.org 2016 membership statistics). IATEFL (based in the UK) is similarly female dominated, with women making up 62 percent of the membership (V. Barnett, Membership Office, IATEFL, personal. communication. 5 November 2013). Moreover, English language learning in Japan tends to be a feminised pursuit with women greatly outnumbering men among English majors in universities (Ryan 2009), and with English widely understood as offering 'feminised academic and professional choices for Japanese women' (Kobayashi 2002, p.181). 
The gendered patterns of international marriage in Japan also provide a possible, though partial, insight into the phenomenon of male-dominance among Western teachers of academic English in Japan. In Japan today, international marriages now represent almost one in thirty marriages (Ministry of Health Labor and Welfare, 2015) and within these figures, a highly gendered and racialised pattern is evident. Where one partner is from the USA or the UK, by far the most common marriage pattern is between a Japanese woman and a Western man. This pattern of Japanese-Western partnering reflects a substantial body of research that has explored the desire expressed by some Japanese women for the West, Western men, and English language learning (see, for example, Bailey 2006, 2007; Kelsky 2001; Ma 1996; Piller \& Takahashi 2006; Takahashi 2013). In the case of foreigners teaching English in Japan, this pattern provides a possible explanation for the greater number of Western men teaching English in higher education, an employment context that tends to correlate with a commitment to longer term residence and marriage to a Japanese spouse. (See Nagatomo 2016, for a discussion of the reverse pattern where foreign women working as English language educators are married to Japanese men).

\section{The study}

The ethnographic study on which the paper is based (Appleby, 2014) adopted a range of methods to develop an understanding of the personal and professional experiences of white Western men and women living and working in Japan as English language teachers in post-compulsory institutions. As far as I am aware it is the only study to have included a specific focus on the gendered experiences of foreign men teaching English language in Japan and was intended, in part, to complement the relatively substantial body of research that has focused on the experiences of Japanese women 
(including English language learners and teachers of English) and foreign female English language educators (for example, Takahashi 2013, Nagatomo 2016). The methods employed in the larger study included an examination of statistical and demographic data on the population of Western men and women in Japan; interviews with 54 Western men and women who were working or had worked as English language teachers in a variety of educational contexts in Japan; and field trips to Japan where I visited and interviewed men and women working in a range of institutions. Field trips generated data from observations, marketing materials, and face-to-face meetings with a range of informants in various private conversation schools, colleges and universities as well as in a range of non-work contexts (such as bars and restaurants). The interview questions asked participants to focus on their qualifications and work history; their perceptions and opinions about Western men and women in Japan (including those working at language teachers); their interpersonal and professional experiences and relationships with Japanese and Western men and women; their views on the benefits afforded to and challenges experienced by Western male and female teachers of English in Japan. In general, the interviews, conducted between 2009 and 2013, were intentionally unstructured and followed the points of interest or concern raised by individual participants. From the corpus of transcribed interview data, this paper focuses specifically on 18 interviews with those Western men who taught English for academic purposes in Japanese higher education institutions.

The participants 
The Western men interviewed for the larger project were selected using snowball sampling and each had worked in Japan for between 2 and 22 years. Participants were from 'Inner Circle' (Kachru 1997) countries and all but one spoke L1 English. Of the 34 male participants in the larger study, 26 had found early employment opportunities in the adult general English conversation school industry, and the longer they stayed in Japan the more likely they were to progress to teaching that included EAP in the higher education sector.

The 18 participants who are the focus of this paper (referred to below as P1 to P18) worked as educators in universities and taught a number of courses at undergraduate and/or postgraduate level. Those courses included academic English and skills for specific disciplines, for example, science, information technology, and international relations. None of the men identified as teachers of general or conversational English All had at least Masters level qualifications, and the majority (11) had Doctorates in language-related areas. The majority (14) of those working in universities had resided in Japan for at least 13 years and were married to a Japanese spouse, a pattern that is integral to understanding the numerical predominance of Western men in EAP positions in Japan. One participant (P9) was interviewed by a male research assistant residing in Japan. From these 18 transcribed interviews, I have selected excerpts which most clearly illustrate the themes emerging from the men's accounts, and demonstrate the various discursive positions and categories produced by the participants (for a more detailed discussion of interview protocol see Appleby, 2014; for ethical dilemmas involved in researching privileged groups and reporting on controversial findings, see Appleby, 2016, 2017). 
Table 1. Participants in the study

\begin{tabular}{|c|c|c|c|}
\hline Name & Age & Marital status & Work in Japan (5-12 years) \\
\hline $\mathrm{P} 1(\mathrm{~s})$ & 30 & $\begin{array}{l}\text { Married, Japanese } \\
\text { Spouse }\end{array}$ & ALT, then university \\
\hline $\mathrm{P} 2 *(\mathrm{~s})$ & 40 & $\begin{array}{l}\text { Married, non- } \\
\text { Japanese spouse }\end{array}$ & ALT, then university \\
\hline P3 (s) & 40 & $\begin{array}{l}\text { Married, Japanese } \\
\text { Spouse }\end{array}$ & $\begin{array}{l}\text { eikaiwa gakkō, then graduate } \\
\text { institution }\end{array}$ \\
\hline P4 (f) & 30 & $\begin{array}{l}\text { Long-term partner, } \\
\text { non-Japanese }\end{array}$ & eikaiwa gakkō, then university \\
\hline & & & Work in Japan (13-22 years) \\
\hline P5* (f) & 50 & $\begin{array}{l}\text { Married, Japanese } \\
\text { Spouse }\end{array}$ & ALT, then university \\
\hline P6 (f) & 50 & $\begin{array}{l}\text { Long-term Japanese } \\
\text { Partner }\end{array}$ & vocational college, then university \\
\hline P7 (s) & 30 & $\begin{array}{l}\text { Married, Japanese } \\
\text { Spouse }\end{array}$ & eikaiwa gakko, then university \\
\hline P8 (e) & 30 & Single & eikaiwa gakkō, then university \\
\hline P9\# (f) & 40 & $\begin{array}{l}\text { Married, Japanese } \\
\text { Spouse }\end{array}$ & eikaiwa gakkō, then university \\
\hline $\begin{array}{l}\text { P10\# } \\
\text { (e) }\end{array}$ & 30 & $\begin{array}{l}\text { Married, Japanese } \\
\text { Spouse }\end{array}$ & $\begin{array}{l}\text { ALT, then eikaiwa gakkō, then } \\
\text { university }\end{array}$ \\
\hline $\begin{array}{l}\mathrm{P} 11^{*} \\
(\mathrm{~s})\end{array}$ & 40 & $\begin{array}{l}\text { Married, Japanese } \\
\text { Spouse }\end{array}$ & eikaiwa gakko, then university \\
\hline P12 (s) & 40 & $\begin{array}{l}\text { Married, Japanese } \\
\text { Spouse }\end{array}$ & eikaiwa gakko, then university \\
\hline P13 (s) & 40 & $\begin{array}{l}\text { Married, Japanese } \\
\text { Spouse }\end{array}$ & eikaiwa gakko, then university \\
\hline P14 (s) & 30 & $\begin{array}{l}\text { Married, Japanese } \\
\text { Spouse }\end{array}$ & $\begin{array}{l}\text { eikaiwa gakko, then corporate } \\
\text { teaching, } \\
\text { then university }\end{array}$ \\
\hline $\mathrm{P} 15^{(\mathrm{f})}$ & 40 & $\begin{array}{l}\text { Married, Japanese } \\
\text { Spouse }\end{array}$ & $\begin{array}{l}\text { eikaiwa gakkō, then ALT, then } \\
\text { university }\end{array}$ \\
\hline P16 (f) & 40 & $\begin{array}{l}\text { Married, Japanese } \\
\text { Spouse }\end{array}$ & University \\
\hline $\mathrm{P} 17(\mathrm{e})$ & 30 & $\begin{array}{l}\text { Married, Japanese } \\
\text { Spouse }\end{array}$ & $\begin{array}{l}\text { ALT, then corporate teaching, then } \\
\text { university }\end{array}$ \\
\hline P18 (f) & 40 & $\begin{array}{l}\text { Long-term Japanese } \\
\text { Partner }\end{array}$ & ALT, then university \\
\hline
\end{tabular}

All names are pseudonyms

* had returned to live in their home country at the time of interview

\# interviewed by a research assistant: an unmarried North American male

(s) interviewed by Skype

(f) interviewed in person

(e) interviewed via email

ALT $=$ Assistant Language Teacher in a Japanese elementary or secondary school 
Eikaiwa gakkō = Private English language conversation school University $=$ in this table includes all formal higher education institutions

It is important to note that the accounts presented by the participants in this article are not intended to represent a transparent window onto an external reality of TEAP in Japan. Rather, the accounts are intended to illustrate a range of discourses that are widely recognised by teachers as circulating in this context and to show how individual participants identify or resist alignment with those discourses. It is also important to note that there may be changes in the conditions experienced by these men in the time since they were interviewed; nevertheless, the most recent accounts of gender as a feature of foreign English language teaching in Japan (for example, Nagatomo 2016) suggest that the broad discourses evident in the men's accounts are still highly relevant in the present day context.

\section{Analytical framework}

My approach to data analysis combines principles from two theoretical fields. The first is that of hegemonic masculinity, as developed by R.W. Connell (2005; see also Connell \& Messerschmidt 2005), which is defined as the most successful, exalted or desirable ways of 'being a man' in a particular context, and by doing so simultaneously defines other masculine styles as inadequate or inferior. Hegemonic masculinity is also conceived as a configuration of gender practice that embodies, guarantees, and legitimises hierarchical relations between men and women. The characteristics of hegemonic masculinity that prevail in the particular context of TEAP in Japan are critically explored below in the analysis of participant interviews. 
The second theoretical strand is situated within a tradition of Foucauldian discourse studies that explore how 'social realities' are built up through participants' 'organization and use of discursive resources and opportunities' (Miller \& Fox 2004: 37). In keeping with this tradition, and drawing on Cameron (2001), my analysis focuses on the ways in which participants' spoken language re/produces discourses that structure the social world of TEAP in Japanese higher education (describing, for example, what kinds of teachers are employed in TEAP), give meaning to events, and offer particular subject positions for English language teachers to take up or to resist.

In relation to this second strand, my analysis is informed by understandings of gender as a discursive achievement rather than a fixed, pre-given entity. The men's accounts are taken as discursive practices that produce and project the subject as a particular type of masculine self (Cameron 2001; Edley 2001) through highly contextualised talk that entails each interviewee's 'social positioning of self and other' (Bucholtz \& Hall 2005: 586). As Bucholtz and Hall (2005) explain, such positioning can be accomplished linguistically in the interview context by the construction, labelling and categorisation of various social actors; by attaching to those categories meanings that invoke particular social and political discourses; and by positioning oneself as a 'particular kind' of person (Pavlenko 2007: 167) in relation to those categories and discourses.

The presentation of the interviewee as a particular type of person also positions the researcher-interviewer. As a white, Western female academic and EAP teacher, I could be seen as both an ally and a threat. As an EAP teacher, I share an awareness of the challenges experienced by language workers who may not achieve the status 
accorded to more highly regarded disciplines in the university system. As a Western woman, however, I could be regarded as someone who may not be always entirely sympathetic to the plight of Western men. I am also an outsider to Japan and therefore not a competitor for jobs: although I have travelled and researched in Japan, I have not worked there as an EAP teacher. My lack of experience in this regard could be seen as a drawback; however, my etic perspective and positioning also offered several advantages in terms of having few preconceptions about gender relations in the world of EAP in Japan and being open to hearing accounts that might not be shared with a female insider.

In my analysis of the men's accounts, the self/other categorisation referred to above occurs in a series of contrasts drawn by participants in their interviews. These contrasts are seen to construct the context-specific features of hegemonic, elite masculinity in TEAP, and to indicate the speakers' positioning in relation to that construction. In my analysis, the two most salient contrasts are drawn, first, between low-status, sexualised, native-speaker language teaching/teachers in conversation schools and high-status, professional, teaching/teachers in universities; and, second, between Western female teachers in universities and Western male teachers in universities in Japan. I argue that articulating these contrasts allows participants to construct and position themselves in relation to an elite professional and masculinised category of EAP employment.

\section{Constructing TEAP as an elite professional activity}

The first way in which TEAP was designated as an elite professional activity was through the articulation of contrasts between TEAP and the teaching of general 
English in the conversation school industry, where most of the men in this study had gained their initial teaching experience in Japan. Disparaging accounts of conversational English teaching focused on the low level of qualifications required by the schools, the poor pay and conditions, the routine nature of the work, and the frequency of romantic and sexualised relationships arising between Western male teachers and Japanese female students. The men's evaluation of the eikaiwa industry as a low status, erotically charged environment echoed much of the research on the gendered and sexualised construction of English language conversation schools in Japan (see, for example, Bailey 2006, 2007; Kubota 2011; Piller \& Takahashi 2006), and reflected understandings in some circles of native-speaker English teachers as the 'white trash of Asia' (interviewee cited in Farrer 2010: 84). As one participant [P7] who was now working in a university explained, teaching in a conversation school was a 'low-paid crappy job' with 'crappy conditions, contract work, no stability, [or] superannuation' where male teachers were valued not for their professional qualifications and expertise:

I'd say that men in some ways were very sort of sexualised by the women [students] [...] I just felt very commodified and sort of- it was all just a bit meaningless [...] In many ways you feel like a whore, I suppose, being involved in it. So it's like [being a] glorified hostess. [P7] ${ }^{2}$

These factors were presented as a reason for leaving the eikaiwa industry and seeking work in the university sector where pedagogical experience and qualifications were

\footnotetext{
2 Transcription codes:

[...] Ellipsis in square brackets indicates some original text has been omitted text- Hyphen indicates a speaker's false start or self-interruption text_Bolded text indicates emphasis by speaker [text] Text in square brackets indicates words inserted to clarify meaning
} 
more highly valued, casual appointments could eventually lead to tenure, and romantic relationships between male teachers and female students were mostly frowned upon. The teaching of English in an academic context was thus - as illustrated in the extract above - represented as a rational, relatively prestigious activity, and a disembodied, non-sexualised professional occupation. So for these men, the opportunity to move into TEAP held the promise of allowing them to construct and perform a higher-status professional identity unencumbered by gendered and sexualised embodiment.

In the men's accounts, the relationship between teachers and students in higher education EAP environments was 'a whole different dynamic' (P7) compared to the eroticised relationships of the eikaiwa industry where teacher-student dating relationships were said to be commonplace, initiated by female students, and often tolerated by school managers. One participant stated that in the 'universities it's a very clear teacher-student relationship' because 'universities aren't places where students come to find [Western teachers as] boyfriends' (P7). Moreover, the men's accounts frequently depicted university students as naïve and child-like, and although young women were 'the keenest students of English language', they were not perceived as 'using [their studies] as a stepping-stone to meet and marry a foreign man' (P5). The relationships in this site were represented as asexually pedagogical, more akin to a father-child relationship than one motivated by sexual desire. Although sexual relationships were acknowledged to occasionally occur between university teachers and students, they were universally rejected as unethical; in contrast, the dating relationships in the eikaiwa schools, where many students were working-age 
adults or housewives, were often regarded with implicit approval (see Appleby, 2013a)

For some of the men, any evidence of female university students' misplaced erotic desire would soon be quashed. For example, one participant described his experience with freshman students as initially tinged with a spark of desire that could be quickly snuffed out:

I get goo-goo eyes from some of the girls, I'm like, 'go away', you know, I feel like a geezer nowadays, an 18 year old girl looking at me with googoo eyes. I'm [so much older], I'm like, 'God, I could be your father!' (P12)

For this teacher of EAP, the aim was not to be 'put on a pedestal' as the embodiment of erotic white masculinity, but instead 'to be respected' for his academic status and seen as 'equal to any other [Japanese] faculty member' (P12).

The adopted identity of a respectable university teacher was further reinforced by the men's marital status, which was frequently mentioned as a means of distancing the men from the promiscuous behaviour associated with single Western men in Japan (Appleby, 2013b). The university then became the location for a reputable married man with academic status, as can be seen in a participant's insistent description of himself and his colleagues:

They're fathers, they're husbands, they're respected, and [...] a lot of them have tenured positions in universities and they're on committees [...] They're guys who have worked hard to make a place and make a 
life in very difficult culture. And I've worked hard too. So I guess if, you know I get hit with this stereotype that you might just be playing the field [with Japanese women] [...] anyone's going to be a bit offended by that.

In brief, the men involved in TEAP distanced themselves from a low-status, eroticised, Western masculinity that was projected onto men teaching general English in the eikaiwa industry. By locating themselves within a higher education EAP context, the men identified with an elite masculinity based on a disembodied (nonsexualised), mature (married, fatherly), professional (academic) ideal, as illustrated in the above extract. In doing so, they articulated a pattern of hierarchical relations among Western men that depends, ironically, on the degree to which a gendered and sexualised embodiment is disavowed. As Connell (2005) points out, an elite form of masculinity such as that articulated by Western men working in EAP is thus constructed through a contest between different ways of 'being a man' and by defining other masculine styles as inadequate or inferior.

\section{EAP as gendered labour}

An elite masculinity may be constructed not only in relation to other (subordinate) forms of masculinity, but also in relation to certain forms of femininity. In this section I turn to the discursive construction of Western women working as EAP educators in Japanese higher education beginning with and the apparently straightforward question of why Western men far outnumber Western women among the population of foreign EAP teachers in Japanese higher education. 
When asked why Western men outnumbered women among English language teachers in higher education, the men often presented a rationale of circular numerical logic: there were more Western men than women in Japan in general, so there were proportionally more Western men employed as EAP educators in the universities:

If you did look at actual statistics, yeah there's more foreign men working at Japanese universities than foreign women, but that's because there's more foreign men in Japan. More foreign men stick around in Japan longer. So, you can't really fault- there's a larger population [of Western men in Japan], then obviously there's going to be larger proportion [of Western men employed in universities]. (P14)

Although a few participants expressed the opinion that Western men may benefit from gender bias in Japanese recruitment patterns, particularly in two year colleges that enrolled mostly female students, they were also quick to point out that the lower number of Western women was not a result of overt discrimination. As one participant commented:

There are a lot more men than women but my own feeling is it's not just that the cards are stacked against the women. ... I wouldn't say it's overt discrimination entirely, although that does exist too. If I were to apply for a good position in a Japanese university and I was competing with women similar to myself from my own society with identical qualifications, in the Japanese situation I think they'd always give me the nod. The justification is 
they feel that the male is more likely to slot in with what [employers] want, which is basically you're going to be 16 hours a day if need be to hang around for meetings and you aren't going to rush off because there are domestic attachments. (P6)

The general understanding that female academics have responsibilities in the domestic sphere that may compete with work demands and have a detrimental effect on their careers has been noted by several other researchers (Hicks 2013; Nagatomo 2012, 2016; Poole 2010; see also this issue $\mathrm{x}$ and $\mathrm{y}$ - eds to add later). On the other hand, several of the men suggested that Western women seeking employment would in fact benefit from institutional moves towards gender equality in Japan. Participants pointed to equal opportunity policies, for example insisting that 'times have changed' and now 'I know lots of universities are very keen to employ [Western] women' (P9). Similar opinions were expressed by men who had experience on university hiring committees and said that employers 'would like to probably have more female foreign teachers' (P7). At the same time, however, it was said that Western women simply weren't available to take advantage of those opportunities:

Like [when] advertising for part-time teachers, $[\ldots]$ we at times have actually wanted to employ a woman, a foreign woman English teacher, just for diversity within the faculty here, because most of the [Japanese staff] who teach in the Masters program are men. I think there's one or two women who've taught in the Masters program, but yeah we've kind of thought it would have been good to have a female teaching here. But we've just never been able 
to recruit anybody. There's just not enough women here teaching English. So that was never an option. (P3)

Again, this appeared to be somewhat of a circular argument, but further questioning about why women didn't stay longer in Japan and take up EAP positions opened a clearer set of discourses about gendered and racialised differences.

The first, and most commonly cited reason offered by the male participants for Western women's departure from Japan was that they were unable to find a male partner:

The foreign women I've known who've left Japan usually do so because they can't find a boyfriend or a husband. At least on one level. As to my knowledge, that's what they've said to me personally. (P14)

Others similarly suggested that most single Western women were likely to prioritise romantic relationships but since they were not successful in attracting Western men, and were not interested in dating Japanese men, they tended not to stay in Japan. In the men's accounts, this gendered and racialised imbalance of desire was then said to materialise as a gender imbalance among Westerners working as EAP educators in the Japanese universities. One participant (P5) described the situation in this way:

So across the board, I'd say most of [the Western women] were very frustrated, if not all, cos they would not be looked at by foreign men. 
Interviewer: Because? Foreign men were interested in Japanese women

P5: Um, I think that's pretty obvious, yeah. I'd say so, yeah. (P5)

Nevertheless, the men did not see themselves as complicit beneficiaries of this cultural phenomenon. In their interviews with me, most of the men professed no personal antipathy towards Western women, and many described individual Western women in positive ways, as 'funny', 'independent and strong' (P7), 'interesting and extroverted, outgoing and intelligent' (P14), or 'very attractive [with] long blonde hair and big blue eyes' (P5). Many of the men also counted Western women among their friends, to the point where they felt 'that it's a real shame to have them leave' (P14). Indeed, a number of men who had several years' experience in Japan, and in relationships with Japanese women, even professed a preference now for Western women on the basis of their 'depth of character and personality' (P17), their shared culture and ability to 'have a good intellectual discussion' in a shared language (P2). On the whole, however, they reported that the few Western women they knew who had stayed long term in Japan were either married to Japanese, or were lesbians: the discourse of 'single women don't stay' was unanimous.

In contrast to positive descriptions of Western women, some of the men asserted that Western women were unappealing, both emotionally and physically, in comparison with Japanese women, with the latter displaying the hallmarks of a more traditional femininity in their petite stature, careful grooming, and polite behaviour. These views were evident across several interviews but particularly by one man who said that 
Western women were 'rude and obnoxious' and 'a lot of them seem to have personal problems' (P9).

I don't know why they would come here. [...] The [Western] women I've met, you know they're affronted by $[\ldots]$ the fact that the Japanese women treat the men so well, the foreign man. But the other is- the opposite is not true, $[\ldots]$ the foreign women don't get treated well by the Japanese men or don't get treated the- the way they want. I think that pisses them off. And ah, the recipients of their uh aah their disappointment and their anger is the white male, I think. (P9)

Such comments echo negative constructions of Western women that have long circulated in Japan (Kelsky 2001). In these accounts, Western women are described as overweight, difficult, and more demanding in their expectations of Western men.

The representation of women articulated by P9 in an interview with a male research assistant, represents Western women as both emotionally unstable as a result of having no male partner, and disgruntled with the good fortune experienced by Western men. Women were represented as the embodiment of irrational passions and emotions. These were qualities that the men often eschewed, controlled or subdued in themselves, so when they were applied to women, they risked rendering the women as too fragile or unstable for the adoption of a properly professional identity appropriate for a university appointment. In this sense, emotionality - and its projection onto Western women - marked a further boundary of exclusion and inclusion in an EAP working life. 


\section{Male bonding and networks}

Although many of the men working as EAP educators in Japanese universities claimed that they experienced no professional benefits as a result of their gender, several of their narratives nevertheless indicated their participation in male networks that likely served to secure their place within the Japanese higher education system. Homosocial networks and alliances, both within the workplace and extending beyond the workplace, bring men together in ways that encourage 'male bonding', bolster solidarity, and 're-create patterns of dominance' that play a role in 'the maintenance of men's power' (Kiesling 2005: 695). As such, these networks, evident in the section below, may appear natural, but are fundamental to male privilege, and contribute significantly to structures of exclusion and power (Sedgewick 1985). Although homosocial networks can serve as a site in which dominant discourses of masculinity are reinforced (for example, through the sexual objectification of women, or displays of physical strength), they may also be the subject of competing discourses presented by men who challenge, resist, or ignore them (Kiesling 2005).

In the past, Usui, Rose and Kageyama (2003) asserted that success in appointments and promotion in the Japanese workplace depended, to a large extent, on making and using one's connections; however, women were 'outside the network' of personal and professional relations that are often crucial to job attainment and promotion (p.114). The university EAP context would appear to be no exception. Nagatomo (2016), for example, notes that many foreigners gain entry into university teaching through personal connections and part-time work, and Whitsed (2011: 115) remarks that 'almost all [initial, part-time] recruitment is via word of mouth and informal contacts'. In his account of English language teaching in Japanese universities, Poole 
(2005) similarly notes that 'there is little time to properly advertise for part-time positions and full-time teachers use their networks to fill the vacancies' (p. 255). For the men in this study, homosocial networking was the commonly mentioned practice that facilitated their initial part-time appointments and, in some cases, supported and advanced their professional careers. In the men's accounts, these informal networks were not designed to explicitly exclude Western women, but were formed over the longer time that men stayed in Japan and tended to be male-dominated. As one participant recounted, 'knowing someone' was more important than high-level qualifications or research track record:

A lot of the jobs are from networking, from- you know you might have a $\mathrm{PhD}$ and you might have great publications and a great resume, but nobody knows you [then] I'm not sure if you're going to get a job at a university in Japan. I think they generally like to know you. (P12)

In some circumstances, Western men identified with homosocial networks produced by Japanese male colleagues and associated with after-hours drinking, dinner, and socialising. These situations were described as predominantly, or even exclusively, male activities, in which a male-dominated Japanese work culture extended beyond official working hours and offered Western men 'opportunities for social interaction that are probably not available to most Western women' (P15). Male bonding in these situations, combined with shared understandings about racialised homosexual normativity - expressed in marriage to a Japanese woman - could lead to profitable employment outcomes, as one participant explained in regard to his promotion from a part-time to a full-time position: 
The professors who supported my full time position in the first place, they made the position for me basically. [...] They knew my [Japanese] fiancée at the time, they knew we were getting married and were going to have a family and settle down in Japan. Maybe [...] they thought that me being on a parttime job situation was not optimal for being married. So if I'm going to get married then I should have a full time job. [...] That's why they made the job for me. $[\ldots]$ As far as I know, the only reason they supported my full time position was because I loved to drink beer with the guys. (P12)

This account of marriage providing a means of integration into professional life was not uncommon and points to just one of the ways in which Western men may be incorporated into the gendered institutional systems that circulate within Japanese higher education and extend beyond institutional boundaries by linking work, leisure, and home life. In common with similar accounts, cultural integration and male collegiality is foregrounded, and it is Japanese rather than Western men who are positioned as upholding the traditional gendered division of labour.

By far the more common description of homosociality centred on the fraternity among Western men, but not all of the men expressed an easy alignment with these Western homosocial activities. Indeed, some of the participants insisted that mixing with groups of other Western men was something that they actively disliked and avoided:

I don't participate in any of the things that they do, like going out every Monday night to the bars. I don't go to bars. The barbecues outside, I don't do those kinds of things. [...] I'm not the kind of person that needs to use those 
kinds of groups. [...] Also these guys are all beer drinkers, and that's one of the reasons they get together. To talk and have beer, and I guess- and burn or- bake or burn sausages there. I've been to- twice or three times to one of those things, just out of politeness, but I can't stay very long. (P16)

The participant's comments clearly signal a dominant masculinity which the participant felt uncomfortable with. Nevertheless, failing to participate in such gatherings could have significant professional consequences:

One of the things that I know I'm missing out is at those gatherings, there's a lot of networking. [They talk about] who is looking for what. Yeah, so I know that men move [jobs] more. It's easier as a man, it's easier to find jobs, if you have the right connections. Because they know who is looking for someone. (P16)

Recruitment through informal networking and the personal recommendation of male friends was 'very much the way it seems to work in Japan - it's all about knowing people and having contacts' (P11), and several men offered accounts of part-time teaching jobs handed on from one to another:

I had one of those special serendipitous meetings where I met a fellow who was leaving a university and he offered me his part-time job and I stepped in, and that was my entrance into higher academia. [...] I've known a number of people at other universities where 'okay, I'm going to leave and I talked to the guys and I'd like to introduce you and if they're okay with you then you 
have the new job'. That makes everybody happy. It's a win-win because they don't have to do a whole lot of work in the search. (P12)

Socialising with groups of men working in EAP contexts was seen by several participants as not only good for finding jobs but also good for harmony in the workplace. Several men spoke about homosocial groups that were formed among Western male colleagues in the workplace but which met socially outside of work at sporting events, bars or clubs. As one participant commented, the ease with which Western men socialised in these groups - particularly in contrast to the perceived isolation of Western women - had a flow-on effect in terms of workplace harmony and satisfaction:

The guys seemed to be having a better social time and therefore seemed happier in the workplace. It seemed to me that [women] feeling isolated a little bit in their private lives was leading to frustrations in the workplace. Those two things, I think, are linked. If you feel happy at home and you're having a satisfying social life, you're happier at work. (P15)

What the men described as women's social isolation was sometimes presented as a 'core cause' of workplace conflict in his own language department (P15). Yet descriptions of the talk that was common within the exclusively male social groups suggest that women may not have been entirely welcomed, with sexism featuring as a discursive practice to cement male solidarity (cf Cameron 1997; Kiesling 2005). According to one participant, for example, the 'strong objectification of female students' was a regular part of talk among Western men in Japan (P17), and a 
collective appreciation of Japanese women would also serve to consolidate views about Western women's unappealing appearance or behaviour. Western women, in several accounts, simply failed to fit with expected gender stereotypes that dictate regimes of feminine comportment in Japan: Western women 'are simply unimagined and just get in the way. The white man wishes that they had just stayed home, whilst the Japanese women perhaps see them as overweight and masculine' (P17) and a problematic misfit in the workplace.

The men who worked in larger English language departments dominated by Western men described a particularly public display of homosociality. Some accounts of workplace practices in these male-dominated locations bore similarities to aspects of Harshbarger's (2012) startling description of corrosive homosociality and gendered bullying by an 'old boys' group of American male teachers in a large EAP department at a prestigious Japanese university. In one account, for example, 'there were only two women teachers out of a total of 16 native speaker teachers', and the department head was 'stereotypically masculine in many ways': he was 'into martial arts and motorbikes' and promoted 'quasi-military' physical displays and challenges, such as judo contests and arm wrestling among his colleagues (P11). According to Schrock and Schwalbe (2009) physical contests of this sort are among the 'manhood acts' that serve to secure male domination in the workplace, and fraternities within an organisation can require, if not demand, participation in these masculine displays in order to validate one's membership in the workplace community. From the perspective of this interviewee, these behaviours were symptomatic of 'the attitudes of lots of Western men in Japan', and of a broader 'cultural landscape' in which a particular style of Western masculinity could flourish (P11). The two women in his 
department were, in his opinion, 'kind of invisible', and 'it was difficult for both of them to establish a presence and find a position that was comfortable and work in that particular environment' (P11).

While traces of masculinity in the style described above were evident in several of the men's accounts, relatively few acknowledged that Western men's homosocial practices might produce a professional environment that was unwelcoming, and even hostile, towards Western women. An example of the difficulty that Western men might find in comprehending the effects of homosociality in the university workplace was provided in an account of a sexual harassment case brought by a Western woman against the men in another large EAP department. In this account, the interviewee wavered in his evaluation of the men's behaviour:

I guess the central charge was that there was a sort of boys' club atmosphere, or boys club in operation within [this department]. [...] To be honest, I thought the charges were pretty spurious, and it wasn't any one thing, it was lots and lots of little things and she felt that there was a sort of laddish atmosphere in the workplace. In retrospect, I think she probably had a good point. I think there was, probably, quite a laddish atmosphere. (P10)

The 'lots and lots of little things' which were the subject of complaint included, in this description, the production and display of a poster showing 'semi-naked women' and 'some suggestive images', a sign fixed on a teacher's door with a pointed reference to 'balls', and a sign-up sheet on which teachers had written 'names with innuendo in them, [...] stupid things like John Wang'. However, the main problem, as 
the manager saw it, was the way the female teacher 'dealt with it', by making a complaint directly to management, rather than directly approaching the men involved to say that she was offended:

If she'd just knocked on the door and said, 'hey, I don't care for this sign on your door, could you take it down?' I would have been only too happy to have removed it $[\ldots]$. But instead, she pieced together this grand conspiracy of male aggression, or male dominance of some sort, which I don't think it was. I think it was more just young guys being a bit stupid really, and a slap on the wrist would have- or at least, she could have brought it to their attention. I think they would have amended their behaviour. (P11)

Yet in a similar situation in another large EAP department, the more direct approach was perceived as equally inappropriate and unproductive. In this male-dominated department, the interviewee narrated an account of one Western woman who 'had a few encounters with some of those [male] teachers' because of her forthright approach:

I think she had a hard time dealing with the- sometimes things get rowdy when you go to those meetings and people start making jokes, and jokes sometimes go in areas that maybe she felt very insulted by the way they talked. [...] I guess she found it just offensive, [...] she would make comments about the way they said things, 'that's sexist' or something like that. [...] Maybe in her own understanding of things she was right, but I thought that in 
these communities I think that a lot of things [you should] just let it go, when they say things like [that]. It's okay, that's the way they see it, that's fine. (P16)

In both these accounts, then, the women's actions in opposing an established EAP workplace culture by naming instances of (perceived) sexism were described as inappropriate, leaving silence as perhaps the only alternative considered acceptable to the male audience. If this is the case, then it seems that women's inclusion in the workplace culture may be at least partially conditional upon their acceptance of a 'pre-existing gendered habitus of institutional life' that supports a continuation of hegemonic masculine values and ways of being (Acker \& Dillabough 2007: 299).

\section{Discussion}

Analysis of the interview data in this paper has pointed to the way elite status is attached to the teaching of EAP in contrast with teaching general or conversational English; the way TEAP - teaching English in university contexts - is reproduced as a male-dominated activity among English-native-speaker teachers, with a largely female-dominated cohort of Japanese learners; and the way Western men teaching in higher education institutions mobilise the status of TEAP to display an enhanced masculinity that is moderate, rational, and professional. At the same time, the study has demonstrated the way discourses articulated by several of the men serve to position gendered and sexualised Others - in this case Western women - as illegitimate participants in the EAP workplace. Although the men's accounts make a claim for TEAP as a disembodied academic occupation, gender and sexuality are deployed as identity gatekeeping tools that serve to police the borders of academic English as an elite, male-dominated professional category. 
This discursive analysis of TEAP masculinity is set against a background of demographic data on the numerical dominance of Western men teaching English in Japanese universities, a dominance that stands in contrast to the feminisation of English language teaching in English L1 contexts and the feminised nature of English studies in Japan. The feminisation and relatively low status of language work globally, and within educational institutions, provide a further incentive for male teachers to distinguish themselves as a professional elite. Especially in those Japanese higher education institutions where there is a critical mass of Western male English language teachers, analysis suggests that the contrasts outlined above support a cultural environment that may prove hostile to teachers who fail to conform to existing (masculine) gendered, (hetero)sexualised, and racialised EAP workplace conditions.

\section{Wider implications for EAP}

The findings reported in this paper relate to a specific cultural and institutional context, yet they speak to wider concerns about the significance of gender and sexuality, and in particular the impact of masculinities, in the globalised world of teaching English for academic purposes.

As discussed above, global English language teaching tends to be a female-dominated occupation and studies of gender in ELT have primarily focused on the experiences of female teachers. There is far less published research on the experiences of male teachers and the discourses of masculinity in ELT or TEAP. However, a small body 
of existing research suggests that East Asian contexts provide employment for a greater proportion of Western men with liberal arts degrees who seek teaching work abroad (Lan 2011). This is the case not only in Japan (Hayes 2013; Hicks 2013) but also in relation to native-English-speaker teachers in China (Stanley 2012), Taiwan (Lan 2011) and South Korea, where male teachers from the West can experience 'a process of re-masculinization' (Cho 2012: 225). Together, these accounts have led Kobayashi (2014: 220) to suggest that white male native-speaker English language teachers may be complicit beneficiaries of a 'male-friendly' culture in East Asian educational institutions. Moreover, since these East Asian studies spotlight the gendered experience of Western English language teachers working abroad, they exemplify an important aspect of a truly globalised industry.

Transformation of gendered hierarchies in the teaching of EAP in these contexts would require a range of shifts that may be difficult to achieve. In the first instance such shifts would require policy initiatives aimed at making the teaching of English in academic contexts female-friendly. However, it must be noted that in cases where gender equity policies exist, there is no guarantee that these effect change on the ground in management attitudes and in the attitudes of men in a male-dominated workforce for whom discrimination can remain invisible. Even more challenging, then, would be the development and enactment of change in deep-seated cultural, institutional, and interpersonal gender ideologies. These are required not only among EAP professionals but also within host cultures, wherever these may be.

\section{References}

Appleby, R. (2017). Dealing with controversial findings. In H. Rose \& J. McKinley 
(Eds.), Doing research in applied linguistics: Realities, dilemmas and solutions, pp. 203-213. New York and London: Routledge.

Appleby, R. (2016). Researching privilege in language teacher identity. TESOL Quarterly, 50(3), 755-768.

Appleby, R. (2014). Men and Masculinities in Global English Language Teaching. Bristol, UK: Palgrave Macmillan.

Appleby, R. (2013a). Desire in translation: White masculinity in TESOL. TESOL Quarterly, 47(1), 122-147.

Appleby, R. (2013b). Singleness, marriage, and the construction of heterosexual masculinities: Australian men teaching English in Japan. PORTAL, Journal of Multidisciplinary International Studies, 10(1), 1-21.

Acker, S \& Dillabough, J. (2007). Women 'learning to labour' in the 'male emporium': exploring gendered work in teacher education. Gender and Education, 19(3), 297-316.

Bailey, K. (2006). Marketing the eikaiwa wonderland: Ideology, akogare, and gender alterity in English conversation school advertising in Japan. Environment and Planning D: Society and Space 24, 105-130. doi.org/10.1068/d418

Bailey, K. (2007). Akogare, ideology, and ‘Charisma Man' mythology: Reflections on ethnographic research in English language schools in Japan. Gender, Place and Culture, 15, 585-608.

Bucholtz, M. \& Hall, K. (2005). Identity and interaction: a sociocultural linguistic approach. Discourse Studies, 7, 585-614.

Butler, J. (1990). Gender trouble: Feminism and the subversion of identity. New York: Routledge. 
Cameron, D. (1997). Performing gender identity: Young men's talk and the construction of heterosexual masculinity. In S. Johnson \& U. Meinhoff (Eds.), Language and masculinity (pp. 47-64). Malden MA: Blackwell.

Cameron, D. (2001). Working with spoken discourse. London: Sage.

Cameron, D. (2005). Language, gender, and sexuality: Current issues and new directions. Applied Linguistics, 26, 482-502.

Cho, J. (2012). Global fatigue: Transnational markets, linguistic capital, and KoreanAmerican male English teachers in South Korea. Journal of Sociolinguistics, $16(2), 218-237$.

Connell, R. W. (2005). Masculinities (2nd ed.). Cambridge, UK: Polity Press.

Connell, R. \& Messerschmidt, J. (2005). Hegemonic masculinity: Rethinking the concept. Gender and Society, 19, 829-859.

Edley, N. (2001). Analysing masculinity: Interpretive repertoires, ideological dilemmas and subject positions. In M. Wetherell, S. Taylor \& S. J. Yates (Eds.), Discourse as Data (pp. 189-228). London and Thousand Oaks: Sage.

Farrer, J. (2010). A foreign adventure's paradise? Interracial sexuality and alien sexual capital in reform era Shanghai. Sexualities, 13(1), 69-95.

Fraser, M. (2011). Exploring the nature and process of professional identity of teachers of English in Japanese higher education. (Unpublished doctoral thesis). University of Wollongong, NSW, Australia.

Harshbarger, B. (2012). A faulty ivory tower: Reflections on directing the ELP from 2006 to 2012. Language Research Bulletin, 12, 1-14. Retrieved from http://web.icu.ac.jp/lrb/ (home page)

Hayes, B.E. (2013). Hiring criteria for Japanese university English-teaching faculty. In S.A. Houghton \& D.A. Rivers (Eds.), Native-speakerism in Japan: 
Intergroup dynamics in foreign language education (pp.132-146). Bristol, UK: Multilingual Matters.

Hicks, S. K. (2013). On the (out)skirts of TESOL networks of homophily: Substantive citizenship in Japan. In S.A. Houghton \& D.A. Rivers (Eds.), Nativespeakerism in Japan: Intergroup dynamics in foreign language education (pp. 147-158). Bristol, UK: Multilingual Matters.

Kachru, B.B. (1997). World Englishes and English-using communities. Annual Review of Applied Linguistics, 17, 66-87.

Kelsky, K. (2001). Women on the verge: Japanese women, Western dreams. Durham: Duke University Press.

Kiesling, S.F. (2005). Homosocial desire in men's talk: balancing and re-creating cultural discourses of masculinity. Language in Society, 34, 695-726.

Kobayashi, Y. (2002). The role of gender in foreign language learning attitudes: Japanese female students' attitudes towards English learning. Gender and Education, 14(2), 181-197.

Kobayashi, Y. (2014). Gender gap in the EFL classroom in East Asia. Applied Linguistics, 35(2) 1-4. doi.org/10.1093/applin/amu008

Kubota, R. (2011). Learning a foreign language as leisure and consumption: Enjoyment, desire, and the business of eikaiwa. International Journal of Bilingual Education and Bilingualism, 14, 473-488. doi.org/10.1080/13670050.2011.573069

Lan, P. C. (2011). White privilege, language capital and cultural ghettoisation: Western high-skilled migrants in Taiwan. Journal of Ethnic and Migration Studies, 37(10), 1669-1693. 
Ma, K. (1996). The modern Madame Butterfly: Fantasy and reality in Japanese cross-cultural relationships. Rutland, Vermont: Charles Tuttle.

MEXT (Ministry of Education, Culture, Sports, Science and Technology Japan) (2012). 大学 統計表 No.178 年齢別·職名別·性別·本務教員数 (Uni 178_Number of Academic Staff by Age Position Gender -incl Non-Japanese). Retrieved from http://www.estat.go.jp/SG1/estat/List.do?bid $=000001038417 \&$ cycode $=0$

Miller, G. \& Fox, K. J. (2004). Building bridges: The possibility of analytic dialogue between ethnography, conversation analysis and Foucault. In D. Silverman (Ed.), Qualitative Research: Theory, Method and Practice (pp. 35-55). London: Sage.

Ministry of Health Labor and Welfare (MHLW) (2015). Trends in percent distribution of marriages by nationality of bride and groom: Japan. Retrieved 24 February 2018 from: https://www.e-stat.go.jp/en/stat$\underline{\text { search } / \text { files?page }=1 \& \text { layout }=\text { datalist } \& \text { tstat }=000001028897 \& \text { cycle }=7 \& y e a r=2}$ $\underline{0150 \& \text { month }}=0 \&$ tclass $1=000001053058 \&$ tclass $2=000001053061 \&$ tclass $3=0$ $\underline{00001053069 \& \text { stat infid }=000031448928 \& \text { result } \text { back }=1 \& \text { second } 2=1}$

Nagatomo, D.H. (2012). Exploring Japanese university English teachers' professional identity. Bristol: Multilingual Matters.

Nagatomo, D.H. (2016). Identity, gender and teaching English in Japan. Bristol: Multilingual Matters.

Schrock, C. \& Schwalbe, M. (2009). Men, masculinity and manhood acts. Annual Review of Sociology, 35, 277-295.

Sedgwick, E.K. (1985). Between men: English literature and male homosocial desire. New York: Columbia University Press. 
Stanley, P. (2012). Superheroes in Shanghai: Constructing transnational Western men's identities. Gender, Place and Culture, 19(2), 213-231. doi.org/10.1080/0966369X.2011.573141

Pavlenko, A. (2007). Autobiographic narratives as data in applied linguistics. Applied Linguistics, 28, 163-188.

Piller, I. \& Takahashi, K. (2006). A passion for English: Desire and the language market. In A. Pavlenko (Ed.), Bilingual minds: Emotional experience, expression and representation (pp. 59-83). Clevedon, UK: Multilingual Matters.

Poole, G.S. (2005). Reform of the university English language teaching curriculum in Japan: A case study. In J. Eades, R. Goodman \& Y. Hada (Eds.) The 'big bang' in Japanese higher education: The 2004 reforms and dynamics of change (pp. 242-273). Melbourne: Trans Pacific Press.

Poole, G.S. (2010). The Japanese professor. Rotterdam: Sense Publishers.

Ryan, S. (2009). Ambivalence and commitment, liberation and challenge: investigating the attitudes of young Japanese people towards the learning of English. Journal of Multilingual and Multicultural Development, 30(5), 405420.

Takahashi, K. (2013). Language learning, gender and desire: Japanese women on the move. Bristol: Multilingual Matters.

Whitsed, C. (2011). Standing in the genkan: Adjunct foreign English language teachers in the Japanese higher education internationalization context (Unpublished doctoral thesis). Perth, Australia: Murdoch University,. 